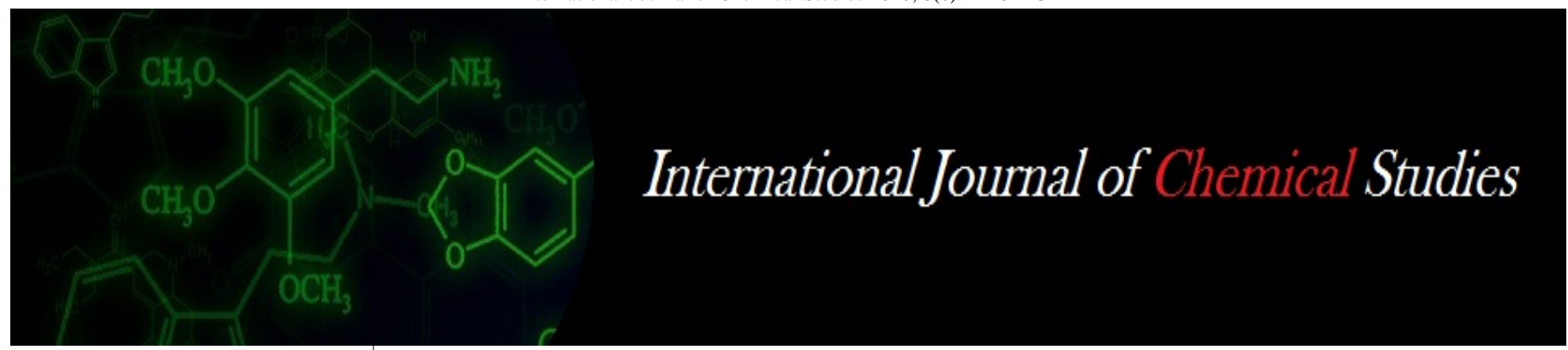

P-ISSN: 2349-8528

E-ISSN: 2321-4902

www.chemijournal.com

IJCS 2020; 8(6): 1128-1134

(C) 2020 IJCS

Received: 12-09-2020

Accepted: 28-10-2020

\section{Puneet Sharma}

Department of Agronomy,

School of Agriculture, Lovely

Professional University,

Phagwara, Punjab, India

Dr. Sandeep Menon

Associate Professor, School of

Agriculture, Lovely Professional

University, Phagwara, Punjab,

India

\section{A review on effect of mulching practices on the crop production}

\author{
Puneet Sharma and Dr. Sandeep Menon
}

DOI: https://doi.org/10.22271/chemi.2020.v8.i6p.10914

\begin{abstract}
Mulching has become the most important practice in modern field production. Mulching is an agricultural technique that involves the use of organic materials (straw, fresh or old hay, animal manures, and other crop residues) and synthetic (inorganic) materials (black plastic, pebbles, and gravels) with the purpose of increasing crop productivity. Mulching practices are also useful for protecting the roots of plant from cold, hot and dry. It also checks evaporation from the soil and improves the micro-climatic air and soil conditions in which the plant is growing. Mulching materials are used to cover the surface of the soil around the plants to create a favorable condition i.e. conservation of soil moisture and temperature for plant growth and development. It included maintain temperatures, reduces salinity and management of weed growth. Mulch has a decisive impact on the yields and quality of crops. Various kinds of mulching materials are used for many agricultural species in several climatic environments, and therefore the results vary consistent with the chosen approach, increasing practices, conditions, and species, so it is difficult to generalize. Mulching operation is also applicable to most of the field crops. Mulching is a beneficiary effect for increasing moisture of soil, reduction in soil erosion, maintenance of soil temperature etc. In agriculture, the black plastic mulch is most used for better crop production. The clear/transparent plastic mulch is used in certain areas due to its enhanced the characteristics of soil warming. Weed control beneath the mulch is preventive to its use. Therefore, Effect of mulching can be increased production of crop in water-deficient areas. In this review relates to the discuss of mulching practices and how, it has a beneficial effect for crop production.
\end{abstract}

Keywords: Mulching, crop growth, yield, soil temperature, soil moisture

\section{Introduction}

Mulch is derived from the German word "Molsch" which means soft to decay. It is known by gardeners as the use of straw and leaves as a spreading on the soil surface to protect the roots of plant. In agriculture, mulching practices are used for several reasons, but conservation of water and control of soil erosion are main objectives for its used in semi-arid and arid regions. The mulching is application of a covering layer of any materials to the soil surface (Kasirajan and Ngouajio, 2012) ${ }^{[32]}$. Many kinds of materials are used to some extent as mulch for controlling weeds and for other purposes. Different types of mulching materials have been utilized in agriculture both in field and home gardening. Farmers use mulching practices as a method of improvement the cultivation soil condition by covering the surface of soil with many types of materials. Bot and Benites (2005) ${ }^{[6]}$ reported that the surface of soil is covered with mulch can add soil organic matter, reduce growth of weed, and minimize the soil erosion. Mulch is of two types i.e. organic mulch, living/inorganic mulch and non-living. Organic mulch includes plant leaves, barks, wood chips, grass clipping that can retain the nutrients found in these organic matters. Inorganic material includes black plastic, pebbles and gravels. Mulching is an effective method to be used for the control of weeds. Mulching is a practice of covering the surface of soil, which creates more favorable conditions for growth and development of plant. This prevents the evaporation of moisture formed on the soil and then limits water loss and conserves moisture. Therefore, it helps to maintain soil temperature fluctuations and high retention of soil moisture, improves the properties of soil, as it adds mineral nutrients to the soil and increases the crop growth and yields (Dilip Kumar et al., 1990) ${ }^{[16]}$. Van Derwerken and Wilcox (1988) ${ }^{[69]}$ reported that mulch can effectively less loss of water vapors, nutrient loss, control of soil erosion and weed problems. According to Magistad et al. (1935) ${ }^{[41]}$ and Weber (2003) ${ }^{[74]}$, the benefits of mulching on annual
Corresponding Author: Puneet Sharma

Department of Agronomy, School of Agriculture, Lovely Professional University, Phagwara, Punjab, India 
and perennial crop growth and yield have long been recognized.

\section{Types of Mulches}

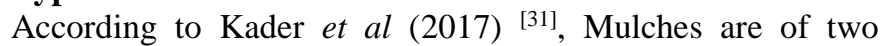
types: i) Organic or biodegradable made of organic materials and, ii) Inorganic mainly made of plastic-based materials, which are used in all over world with the crop selection.

Organic Mulches: Organic mulches are those natural origin materials i.e. plant and animal materials, which can decompose naturally. Mulch materials includes plant residues like as straw (rice and wheat), hay, leaf mold, compost, wood products and animal manures. Organic mulch materials such as grain straw, fresh or old hay and other crop residues used as mulch are biodegradable, and if used properly, demonstrate all the advantages of any mulch practice with the possible exception of early-season soil warming like conservation of soil and water, increased soil biological activity and improved soil properties i.e. physical and chemical properties (Cooper, 1973; Murugan and Gopinath, 2001) [12, 46]. Sarolia and Bhardwaj (2012) [58] reported that organic mulches are efficient in reducing nitrates leaching, improving physical properties of soil, preventing erosion, supplying organic matter, regulating temperature and water retention, improving nitrogen balance, increasing biological activity and participating in nutrient cycles. Bhardwaj (2011) ${ }^{[5]}$ stated that natural materials are not spread over crops growing easily and require a lot of human labour. But organic mulch attracts the cutworms, slugs and insect-pests that eat them. Organic mulch is easily decomposed and require frequent replacements. However, mulch refers to a lot of heat and keeps the soil cool and prevents evaporation as soil and is important in the hot and dry climatic conditions of the soil.

Grass Clipping: Grass clipping is easily available mulch materials across the country. Grass clipping mulch materials provides nutrients, especially nitrogen and potassium to the soil if fresh grass is incorporated. However, the application of green grass in the rainy season may result in the development of its root system that will be detrimental to the growth of plants. So, the use of dry grass is suggested as a mulch material.

Straw: Straw mulching materials i.e. paddy and wheat straw are the commonly used for crop production. Although the straw mulch is very less in nutrient value, but after decomposition it makes more fertile soil. The straw mulch has a longer life as compared to other organic mulches. Straw mulching can improve the availability of soil nitrogen, increase the growth and development of plants and also affect the physical and chemical properties of the soil (Fang et al., 2011; Govaerts et al., 2007) ${ }^{[20,23]}$.

Dry leaves: Leaves are easily available material and good for mulching. However, during winter, leaves are best for protects the inactive plants by keeping them dry and warm. But due to less weight, they can also be blown away even by air. Dry leaves of sugarcane are used for mulching purposes and are more effective for the control of weeds in the field. (Lorenzi et al., 1989) ${ }^{[40] .}$

Compost: Compost is the best mulch material for improving the health of soil. It enhances the microbial population, improves soil structure and also provides plant nutrients.
Newspaper: The newspaper helps to control the mulching weeds. The application of newspaper mulch on the day of air should be avoided. The paper mulch can provide a solution to the problem of disposal of plastic mulch, as they can completely decomposed after utilization and be incorporated into the soil. However, paper mulches are low cost than biodegradable mulch, they are costly than plastic, their shorter life span and they can expand and contract in ways that cause problems for crop plants (Merfield, 2002; Salokangas, 1973) $[43,56]$.

Sawdust: Sawdust, obtained during the finishing operation of the wood, the nutrient value is very less because it contains only half the nutrients of the straw mulch material. They get slowly decomposed and it is acidic in nature. Sawdust mulch should not be use in acidic type of soil.

\section{Inorganic Mulches}

The inorganic mulches materials do not decompose, or they break down gradually after a long time period. The various kinds of inorganic mulch are rocks or gravel, plastic sheeting, landscape fabrics, and rubber mulch. The inorganic materials used as mulch can certainly add attractive value and they work proper well to suppress the weeds.

Gravel, Pebbles and Crushed stones: It is a layer of small rock i.e. 3-4 cm, provides good weed control. All these materials are used for perennial crops as a mulch. But they also reflect solar radiation and can create a very hot environment in the soil during summer.

\section{Plastic Mulch}

The largest amount of plastic mulch is used for commercial crop production. Both, black and transparent films are commonly used for mulching. The plastic materials used as mulch are polyethylene films or poly vinyl chloride (PVC). On account of its higher permeability to long wave radiation, it can enhance the temperature around plants at night in the winter season. Therefore, the polyethylene film mulch is chosen as a mulching material for production of crop. Decoteau et al. (1988) ${ }^{[13]}$ reported that the plastic mulches provide a range of weed control levels based on the amount of light transmission through mulch. During the growing season, $64 \%$ to $98 \%$ reduced weed emergence by plastic mulch (Egley, 1983) ${ }^{[19]}$. Plastic film mulching can enhance temperature of soil (Liu et al., 2003; Peng et al., 1999) ${ }^{[38,52]}$ and high temperatures can not only favor $\mathrm{N}$ mineralization (Wilson and Jefferies, 1996) ${ }^{[77]}$ but also plant nitrogen uptake (Liu et al., 2003) ${ }^{[38]}$. Wien et al. (1993) ${ }^{[75]}$ reported that benefits of crop production from polyethylene mulch are well documented and include more root growth and nutrient uptake. Plastic mulch are of two types:

Photo-degradable plastic mulch: The photo-degradable plastic mulch is used for shorter period because it is destroyed by sunlight.

Bio-degradable plastic mulch: The bio-degradable plastic mulch is degraded easily into soil over a time period.

Different colors of plastic film and benefits: The soil environment can be properly managed by a proper selection of plastic mulch structure, color and thickness. The plastic films are available in various colors including black, transparent, white, silver, blue, red, etc. But the selection of 
the color of the plastic mulch film depends on specific goals. Generally, the following types of plastic mulch films are used in crop productions:

1. Black plastic film: Black plastic film helps in preserve moisture in soil, reduce outgoing radiations and also reduce the weed growth.

2. Transparent film: Clear/transparent film increases the temperature of the soil and is preferably used for Solarization.

3. Reflective silver film: This type of plastic film usually keeps the plant root zone temperature cooler.

\section{Effect of mulch on soil}

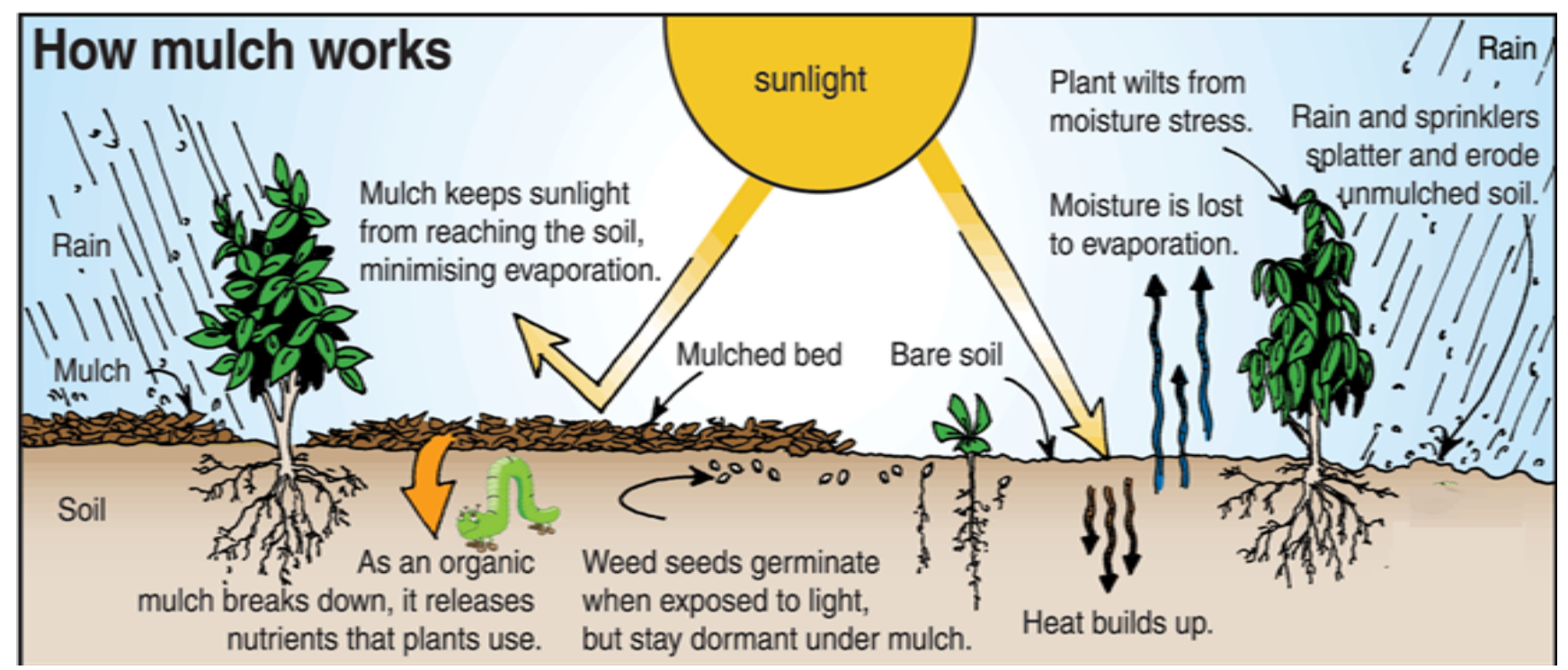

Fig 1: Show the how mulch works

Soil moisture conservation: Mulching is one of the important purposes for conservation of soil moisture. The conditions of micro-climate are favorably influenced by optimal soil moisture. When the surface of soil is covered with mulch materials, it helps to minimize evaporation and maximize infiltration of rainwater during the growing season and also helps to control the weed growth. Plastic mulch helps to shed excessive water away from the crop root area during the period of excessive rain fall. This can reduce the frequency of irrigation and the amount of water used. Polyethylene mulch is used in the field, increased temperature of soil especially in early spring season, reduction problems of weed, increased moisture conservation, reduction in certain population of insect-pests, increase yield of crop and greater efficient use of nutrients in the soil (Orzolek et al., 1993) ${ }^{[49]}$. Crop residues or mulch at the surface of soil serve as shade, which acts as a vapor barrier against the loss of moisture from the soil, thereby reducing surface runoff. Hatfield et al. (2001) [26] stated that 34-50 percent decrease in evaporation of soil water as the result of crop residue mulching. The shredded newspaper and wheat straw provided a moister and cooler environment of soil than bare soil under sweet corn, field corn, soybean and processing tomatoes in Wisconsin, USA (Munn, 1992) ${ }^{[45]}$.

Reduce infiltration rate: The crop residue mulch presence on the interface of soil-atmosphere has a directly affects the evaporation from the soil and infiltration of rainwater into the soil. The total intake of water increases due to the formation of loose soil surface through mulching. The mulch cover reduces soil surface runoff and holds more rainwater on the surface of the soil giving more time to infiltrate the soil. Rajput and Singh (1970) [54] reported that the conserved moisture of soil is higher in treatment of straw mulch which is extent of 55 percent more compared to control. Cover the surface of soil minimized the volume of irrigation water require by pepper crop and onion crop by about $14-29 \%$ and 70\% respectively (Abu-Awwad, 1998 and Abu-Awwad, 1999) ${ }^{[1,2]}$.

Maintain soil temperature: Mulching decreases the temperature of soil in summer, increases it in winter and prevents extremes of temperature. During the summer, mulching preserves soil moisture due to low evaporation. The temperature of the soil changes according to the ability of mulching materials to transfer and reflect solar energy. Plastic mulching enhanced soil temperature from 0.9 to $4.3^{\circ} \mathrm{C}$ in the seedling stage, 1.6 to $2.3^{\circ} \mathrm{C}$ in the bud initiation stage and 0.8 to $1.9^{\circ} \mathrm{C}$ in the flowering stage (Chen and Yin, 1989) ${ }^{[11]}$. Duhr and Dubas (1990) ${ }^{[17]}$ observed that soil temperature increases of 2.9 to $3.3^{\circ} \mathrm{C}$ with transparent, photo-degradable polythene film mulching. Devi Dayal et al. (1991) [15] concluded that wheat straw mulch increased temperature of soil from 2 to $3^{\circ} \mathrm{C}$. The temperature of soil can be greater up to $7^{\circ} \mathrm{C}$ under the clear plastic mulch compared to bare soil (Lamont, 1993) ${ }^{[35]}$. An increase the average soil temperature by $2.4^{\circ} \mathrm{C}$ at a depth of $15 \mathrm{~cm}$ under transparent film and an increase of $0.8^{\circ} \mathrm{C}$ temperature under black film (Park et al., 1996) [50]. Many advantages of plastic mulching for agriculture including maintaining the soil temperature and humidity, preventing the soil borne diseases and attack by soil pests and accelerating growth (Sciortino, 2001) ${ }^{[60]}$. According to Lamont (2005) ${ }^{[36]}$, the condensation on inner side of mulch material absorbs the long wave radiations emitted by soil, because of that slowing the coolness of the soil at night.

Addition of organic matter: The benefits of organic mulches adds plant nutrients and organic matter into the soil and improve the soil properties after decomposition, which in turn maximum yield of crops. Mulching increased soil moisture, organic matter content, which leads to an environment suitable for root penetration. Under mulch, the soil remains 
loose and friable or increased soil microbial activity and proper aeration. Dilip Kumar et al. (1990) ${ }^{[16]}$ reported that organic mulches not only preserve the moisture of soil, but they also increase the nutrients in soil through addition of organic matter. Lal et al. (1980) ${ }^{[34]}$ reported that the organic matter was significantly higher, when large amount of mulch was applied. Increase organic matter content in soil due to decomposition of applied mulch. Increased soil organic carbon contents due to applications of crop residue mulches (Duiker and Lal, 1999; Havlin et al., 1990; Paustin et al., 1997; Saroa and Lal, 2003) ${ }^{[18,27,51,57] .}$

\section{Effect of mulching on plants}

Plant growth \& development: The application of mulching provides a favorable environment for growth and development resulting in more vigorous, healthy plants that are probably high resistant to the insect-pest injury. Jones (1991) ${ }^{[30]}$ reported that increase in temperature and moisture content of soil encourage the growth of plant roots leading to higher plant growth. Mulching effect on plants is operative through the effect of mulch on moisture, temperature, structure and erosion of soil. Less evaporation is the main reason of plant growth and thereby the maximum production of crop due to mulch.

Improve quality and yield: The most common response to mulch is an increase of total yield. (Locascio et al., 1985; Van Derwerken and Wilcox, 1988; Wien and Minotti, 1987) [39, 69, 76]. Yield increase can be attributed to more favorable soil moisture and nutrient utilization (Chalfant et al., 1977) ${ }^{[10]}$. The yield difference can be attributed to conservation of soil moisture, increased temperature of soil, control of weeds and enhanced uptake of mineral nutrient in the mulched plot through the improvement of root temperatures (Al-Assir et al., 1992; Brown et al., 1993; Decoteau et al., 1990; Ham et al., 1993; Orozco et al., 1994; Tindall et al., 1991; Wien et al., 1993) ${ }^{[4,8,14,25,48,65,75]}$. The plastic mulch installed proper and it helps to keep the soil from splashing on plants during the rain that can reduce grading time. To keep quality of early potatoes, cabbage and other some vegetables can be improved by the straw mulch. The straw mulch is probably due to better plant growth which is also controlled by soil temperature and soil moisture with minimal fluctuations. Uppal et al. (2001) [68] achieved that potato mulched tubers contain about 46 percent less in reducing sugar than the normal crop. Adeoye (1984) ${ }^{[3]}$ observed that grass mulching enhanced the grain yield of maize crop by $15 \%$ to $22 \%$ and millet crop by about $10 \%$ in northern Guinea and Sudan savanna regions of Nigeria. Ramakrishna et al. (1991) [55] pointed out that effective weed control resulted in improvement in yield parameters and yield of groundnut. Tamilselvan et al. (2001) [63] reported that the press mud mulching material eventually recorded highest cane and sugar yield in sugarcane crop. The plastic mulch has the potential to alters the temperature of soil, less use of crop water, improve crop quality and control weeds, thereby improving crop development and increasing yields (Lamont, 2005; Ngouajio and Ernest, 2005; Waterer, 1999; Waterer, 2000) [36, 47, 72, 73]. The mulches modified the microclimate by modifying the soil temperature, soil moisture and evaporation and the modified microclimate influenced the yield contributing characters of tomato (Gandhi and Bains, 2006) ${ }^{[22]}$. Increase in grain yield of corn under mulching conditions may be due to increased soil moisture storage and suppression of weed growth (Mastana, 1998) ${ }^{[42]}$. Tolk et al. (1999) ${ }^{[66]}$ reported that mulch in turn increases moisture of soil and the availability of nutrients into the roots of plants, leading to grain yield. Transplantation of spring maize with plastic film mulching improved the ecological environment of the soil, increased soil temperature and soil water content, promoted maize growth and maturation, and increase in crop yield (Liu et al., 2002) ${ }^{[37]}$.

Effect of mulching on weed control: Mulching practices or covering the surface of soil can control germination of weed seed or physically suppress seedling emergence. The main purpose of mulch practice aims to cut the light of weeds and suppress their growth and development. All types of organic \& inorganic mulch cover the soil and performs physical barrier for weeds. Mulching reduces the germination and nourishment of many weeds by providing a physical barrier. The operation of mulching favors reduction of weed growth, weed seed germination and keeps weeds under control (Vander et al., 1986) ${ }^{[70]}$. Merwin et al. (1995) ${ }^{[44]}$ stated that loose materials like bark, straw and composted municipal green waste can provide successful management of weeds. Waterer (2000) ${ }^{[73]}$ reported that the sawdust is a reformer of soil and weed suppression as it retains moisture of soil, more percolation and infiltration, less evaporation, less surface runoff etc. and growth of weed can be sufficient under the clear mulch.

\section{Effect of mulching on insect pest control}

The cultural management practices, including the utilization of cover crops and mulches, are environmentally safe methods for handling certain specific insect pests (Prasifka et al. 2006; Schmidt et al. 2007; Teasdale et al. 2004; Tremelling et al. 2002) [53, 59, 64, 67]. Brown and Tworkoski (2004) ${ }^{[9]}$ reported that mulching is successful way to supply shelter for predatory insects and manage weeds. Johnson et al. (2004) ${ }^{[29]}$ observed that Mulches help to preserve the soil moisture needed for plant vigor and to encourage tolerance in plants for the attack of insect pests. Lamont (1993) [35] reported that polyethylene mulches have been used for possible reduction in insect and disease pests. Sciortino (2001) ${ }^{[60]}$ and Stapleton et al. (2005) ${ }^{[61]}$ reported that the capacity of clear mulch to produce soil temperatures more enough to control weeds, nematodes and plant pathogens forms the basis for the soil solarization process. The clear/transparent polyethylene mulch features a repellent impact on pests and vectors insects, like thrips (Greenough et al., 1990) ${ }^{[24]}$, aphids (Jones, 1991) ${ }^{[30]}$ and whiteflies (Kelly et al., 1989) ${ }^{[33]}$. Farias-Larios and Orozco-Santos (1997) [21] reported that the beneficial effect of clear plastic mulch reduce the population of aphid.

\section{Effect of mulching on soil micro-flora}

Mulching stimulates the soil micro-organisms such as bacteria, actinomycetes, fungi, algae and other organisms such as earthworms etc. due to loose, soil conditions wellaerated, uniform soil moisture and soil temperatures thus resulting in a high rapid breakdown the organic matter of soil and release of mineral nutrients for crop growth. Under the layer of mulch, earthworms proliferate and help to improve the soil aggregate stability and infiltration etc. Surya et al. (2000) ${ }^{[62]}$ reported that greater moisture of the soil profile under mulch has significant implications on water use by crop and on soil reactions that manage the biological nitrogen fixation and nutrients availability. The mulching practices gave positive impact on the soil biota (Brown et al., 2001) ${ }^{[7]}$. Holland (2004) ${ }^{[28]}$ stated that the soil biota enhances under 
mulched soil environment leading to improve nutrient cycling and produce organic matter over a period of many years.

\section{Selection of mulching}

The selection of suitable mulching material depends on the types of materials, ecological locations, colors, thickness, perforations and availability of materials, cost-effectiveness, and feasibility of the crop (Wang et al., 2015) ${ }^{\text {[71]. The }}$ comparative characters of the selection of organic and plastic mulching are discussed below:

Table 1: Show the subject organic and plastic mulching

\begin{tabular}{|c|c|c|c|}
\hline S. No. & Subject & Organic mulching & Plastic mulching \\
\hline 1 & Materials type & Bio-based cellulose, chips, leaf, paper & Acetate, polyethylene, polymeric material \\
\hline 2 & Durability & Temporary & Long-lasting \\
\hline 3 & Thickness & $3-5 \mathrm{~cm}$ & \multicolumn{1}{|c|}{ Bm } \\
\hline 4 & Colors & Natural & Black, silver, white etc. \\
\hline 5 & Weed control & Effective but grass material grows weed & High weed competition except the transparent color \\
\hline 6 & Solarization & Not effective in some cases & Effective by boosting soil temperature \\
\hline 7 & Pest-management & Reduced thrips and fungal disease & Reduced thrips, spider mites, and whiteflies \\
\hline 8 & Availability & Locally available & Not locally available \\
\hline 9 & Priority mulch & Straw (rice and wheat) & Black plastic \\
\hline 10 & Costing & Cheap & Expensive \\
\hline 11 & Labor & Not laborious & Discarded and buried that polluted soil \\
\hline 12 & Degradability & Naturally decompose and add nutrients & Fast growth \\
\hline 13 & Plant growth & Moderate growth & Restricts water flow \\
\hline 14 & Water infiltration & Increases & \\
\hline
\end{tabular}

\section{Conclusion}

From the above review, it can be concluded that different types of organic and inorganic mulching materials should be extensively used for conservation of soil and moisture/water, soil temperature moderation, soil health maintenance and increased soil productivity. Mulching provides various advantages to production of crop through conservation of soilwater, improved physical, chemical and biological properties of the soil, increased soil biological activity. Organic mulch also provides organic matter and mineral nutrients, stimulates soil micro-flora, increases the biological activity of soil and participates in the nutrient cycle. In agriculture, the black plastic mulch is most used for better crop production. The clear/transparent plastic mulch is used in certain areas due to its enhanced the characteristics of soil warming. Weed control beneath the mulch is preventive to its use. Therefore, effect of mulching can be increased production of crop in waterdeficient areas.

\section{References}

1. Abu-Awwad AM. Effect of mulch and irrigation water amounts on soil evaporation and transpiration. Journal of Agronomy and Crop Science 1998;181:55-59.

2. Abu-Awwad AM. Irrigation water management for efficiency water use in mulched onion. Journal of Agronomy and Crop Science 1999;183:1-7.

3. Adeoye KB. Influence of grass mulch on soil temperature, soil moisture and yield of maize and gero millet in a savanna zone soil. Samaru Journal of Agricultural Research 1984;2:87-97.

4. Al-Assir IA, Rubeiz IG, Hoover R. Yield response of greenhouse cantaloup to clear and black plastic mulches. Biological agriculture and horticulture 1992;8:205-209.

5. Bhardwaj RL. Benchmark survey on effect of mulching material on crop production. Krishi Vigyan Kendrs, Sirohi, MPUAT Udaipur, 2011, 12-15.

6. Bot A, Benites J. The importance of soil organic matter key to drought-resistant soil and sustained crop production. FAO Soils Bulletin, 2005, 80.

7. Brown GG, Pasini A, Benito NP, De Aquino AM, Correia MEF. Diversity and functional role of soil macrofauna communities in Brazilian no-tillage agroecosystems: a preliminary analysis. International Symposium on Managing Biodiversity in Agricultural Ecosystems, Montreal, Canada, 2001.

8. Brown JE, Dangler JM, Woods FM, Tilt KM, Henshaw MD, Griffey WA et al. Delay in mosaic virus onset and aphid vector reduction in summer squash grown on reflective mulches. HortScience 1993;28(9):895-986.

9. Brown MW, Tworkoski T. Pest management benefits of compost mulch in apple orchards. Agric. Ecosyst. Environ 2004;103:465-472.

10. Chalfant RB, Jaworski CA, Johnson AW, Sumner DR. Reflective film mulches, millet barriers, and pesticides: Effects on watermelon mosaic virus, insects, nematodes, soil borne fungi, and yield of yellow summer squash. Journal American Society of Horticultural Science. 1977;102:11-15.

11. Chen QE, Yin JS. Effects of plastic mulch on soil properties and cotton growth in saline-alkali soils. Journal of Soil Science, China 1989;20:1-3.

12. Cooper AJ. Root temperature and plant growth: A review. Commonwealth Bureau of Horticulture and Plantation Crops, East Malling, Maidstone, Kent, UK, 1973.

13. Decoteau DR, Kasperbauer MJ, Daniels DD, Hunt PG. Plastic mulch colour effects on reflected light and tomato plant growth. Scientia horticulturae 1988;34:169-175.

14. Decoteau DR, Kasperbauer MJ, Hunt PG. Bell pepper plant development over mulches of diverse colours. HortScience 1990;25:460-462.

15. Devi Dayal, Naik PR, Dongre BN. Effect of mulching on soil temperature and groundnut yield during rabi-summer season. Groundnut News 1991;3:4-5.

16. Dilip Kumar G, Sachin SS, Kumar R. Importance of mulch in crop production. Indian Journal of Soil Conservation 1990;18:20-26.

17. Duhr E, Dubas A. Effect of covering the soil with plastic film on the dynamics of plant development and yield of maize sown on different dates. Prace Komisji Nauk Rolniczych Ikomisji Nauk Lesnych 1990;69:9-18.

18. Duiker SW, Lal R. Crop residue and tillage effects on carbon sequestration in a Luvisol in central Ohio. Soil Tillage Research 1999;52:73-81. 
19. Egley GH. Weed seed and seedling reductions by soil solarization with transparent polyethylene sheets. Weed Science 1983;31:404-409.

20. Fang SZ, Xie BD, Liu D, Liu JJ. Effects of mulching materials on nitrogen mineralization, nitrogen availability and poplar growth on degraded agricultural soil. New Forests 2011;41:147-162.

21. Farias-Larios J, Orozco-Santos M. Effect of polyethylene mulch colour on aphid populations, soil temperature, fruit quality and yield of watermelon under tropical conditions. New Zealand Journal Crop Horticulture 1997;25:369-374.

22. Gandhi N, Bains GS. Effect of mulching and date of transplanting on yield contributing characters of tomato. Journal Research Punjab Agriculture University India 2006;43:6-9.

23. Govaerts B, Sayre KD, Lichter K, Dendooven L, Deckers J. Influences of permanent raised bed planting and residue management on physical and chemical soil quality in rain fed maize/wheat systems. Plant and Soil 2007;291:39-54.

24. Greenough DR, Black LL, Bond WP. Aluminum surfaced mulch: an approach to the control of tomato spotted wilt virus in solanaceous crops. Plant Disease 1990;74:805-808.

25. Ham JM, Kluitenberg GJ, Lamont WJ. Optical properties of plastic mulches affect the field temperature regime. Journal of the American Society for Horticultural Science 1993;118:188-193.

26. Hatfield JL, Sauer TJ, Prueger JH. Managing soils to achieve greater water use efficiency: A review. Agronomy Journal 2001;93:271-280.

27. Havlin JL, Kissel DE, Maddus LD, Claassen MM, Long JH. Crop rotation and tillage effects on soil organic carbon and nitrogen. Soil Science Society of American Journal 1990;54:448-452.

28. Holland JM. The environmental consequences of adopting conservation tillage in Europe: Reviewing evidence. Agriculture Ecosystems and Environment 2004;103:1-25.

29. Johnson JM, Hough-Goldstein JA, Vangessel MJ. Effects of straw mulch on pest insects, predators, and weeds in watermelons and potatoes. Environmental Entomology. 2004; 33:1632-1643.

30. Jones RAC. Reflective mulch decreases the spread of two non-persistently aphid transmitted viruses to narrow lupin (Lupinus angustifolius). Annals of applied biology 1991;118:79-85.

31. Kader MA, Senge M, Mojid MA, Ito K. Recent advances in mulching materials and methods for modifying soil environment. Soil Tillage Research 2017;168:155-166.

32. Kasirajan S, Ngouajio M. Polyethylene and biodegradable mulches for agricultural applications: a review. Agron Sustain Dev [Internet]. 012;32:501-529.

33. Kelly JW, Adler PH, Decoteau DR, Lawrence S. Colored reflective mulches surfaces to control whitefly on poinsettia. Hort Science 1989;24:1045-1049.

34. Lal R, Vleeschauwer D, De Nganje RM. Changes in properties of a newly cleared tropical Alfisols as affected by mulching. Soil Science Society of American Journal. 1980;44:827-833.

35. Lamont Jr WJ. Plastic mulches for the production of vegetable crops. HortTehnology 1993;3:35-39.
36. Lamont Jr WJ. Plastics: Modifying the microclimate for the production of vegetable crops. Hort Technology 2005;15:477-481.

37. Liu J, Xu SA, Zhou GY, Lu HH. Effects of transplanting multi-cropping spring maize with plastic film mulching on the ecological effect, plant growth and grain yield. Journal of Hubei Agriculture College 2002;2:100-102.

38. Liu XJ, Wang JC, Lu SH, Zha, ng FS, Zeng XZ, Ai YW et al. Effects of non-flooded mulching cultivation on crop yield, nutrient uptake and nutrient balance in rice-wheat cropping systems. Field Crops Research 2003;83:297311.

39. Locascio SJ, Fiskel JGA, Hauck RD. Nitrogen accumulation by pepper as influenced by mulch and time of fertilizer application. Journal American Society of Horticultural Science 1985;110:325-328.

40. Lorenzi HJ, Gandini MO, Gazon AL. Trash blankets: the potential to control weeds and the effect on ratoon cane development. In: Proceedings of the XX ISSCT Congr. Sao Paulo, 1989, 571-575.

41. Magistad OC, Farden CA, Baldwin WA. Bagasse and paper mulches. Journal American Society of Agronomy 1935;27:813-825.

42. Mastana PS. Effect of crop residue management practices on nitrogen balance in water eroded cultivated land. M.Sc. thesis, Punjab agricultural university, Ludhiana, India, 1988.

43. Merfield C. Organic Weed Management: A Practical Guide, 2002, 1-30.

44. Merwin IA, Rosenberger DA, Engle CA, Rist DL, Fargione M. Comparing mulches, herbicides and cultivation as orchard groundcover management systems. Hort Technology 1995;5:151-158.

45. Munn DA. Comparisons of shredded newspaper and wheat straw as crop mulches. Hort Technology 1992; 2:361-366.

46. Murugan M, Gapinath G. Effect of organic and inorganic mulches on growth and flowering of crossandra (Crossandra undulaefolia Salisb) cv. "Saundarya", Research on crops 2001;2:346-350.

47. Ngouajio M, Ernest J. Changes in the physical, optical, and thermal properties of polyethylene mulches during double cropping. Hort Science 2005;40:94-97.

48. Orozco SM, Lopez AO, Perez ZO, Delgadillo SF. Effect of transparent mulch, floating row cover and oil sprays on insect populations, virus diseases and yield of cantaloup. Biological Agriculture and Horticulture 1994;10:229-234.

49. Orzolek MD, Murphy J, Ciardi J. The effect of coloured polyethylene mulch on the yield of squash, tomato and cauliflower. Final Report to the Pennsylvania Vegetable Marketing and Research Commodity Board. The Pennsylvania State University, USA, 1993.

50. Park KY, Kim SD, Lee SH, Kim HS, Hong EH. Differences in dry matter accumulation and leaf area in summer soybeans as affected by polythene film mulching. RDA Journal of Agricultural Sciences. 1996; 38:173-179.

51. Paustin K, Collins HP, Paul EA. Management controls of soil carbon. In: Paul, E et al. (eds.), SOM in Temperate Agroecosystems: Long Term Experiments in North America, CRC Press Inc, 1997, 15-49.

52. Peng S, Shen K, Wang X, Liu J, Luo X, Wu L. A new rice cultivation technology: plastic film mulching. Int Rice Res Newsl 1999;24:9-10. 
53. Prasifka JR, Schmidt NP, Kohler KA, O’Neal ME, Hellmich RL, Singer JW. Effects of living mulches on predator abundance and sentinel prey on a corn-soybeanforage rotation. Pest Management 2006;35:1423-1431.

54. Rajput RK, Singh M. Efficacy of different mulches in conserving soil moisture in cotton. Indian Journal of Agronomy 1970;15:41-45.

55. Ramakrishna A, Ong CK, Reddy SLN. Integrated weed management for rainfed groundnut. Journal Plant Prot. Tropics 1991;8:111-119.

56. Salokangas K. Effect of polyethylene and paper mulching on yield and earliness of pickling cucumber. Acta Horticulturae 1973;27:223-226.

57. Saroa GS, Lal R. Soil restorative effects of mulching on aggregation and carbon sequestration in a Miamian soil in Central Ohio. Land Degrade Development 2003;14:481-493.

58. Sarolia DK, Bhardwaj RL. Effect of mulching on crop production under rainfed condition: A Review. International Journal of Research in Chemistry and Environment 2012;2:8-20.

59. Schmidt NP, O’Neal ME, Singer JW. Alfalfa living mulch advances biological control of soybean aphid. Environmental Entomology 2007;36:416-424.

60. Sciortino A. Mulching, in what conditions? Colture Protette 2001;30:39-43.

61. Stapleton JJ, Molinar RH, Lynn-Patterson K, McFeeters SK, Shrestha A. Soil solarisation provides weed control for limited resource and organic growers in warmer climates. California Agriculture 2005;59:84-89.

62. Surya JN, Puranik JB, Zadode SD, Deshmukh SD. Effect of wheat straw incorporation on yield of green gram and wheat, soil fertility and microbiota. Journal Maharashtra Agricultural University 2000;25:158-160.

63. Tamilselvan N, Budhar MN, Suresh M, Giridharan S. Effect of different mulching materials on weed control, yield and quality of sugarcane. Proceedings of the 63rd Annual convention of the Sugar Technologists Association of India, Jaipur, 2001, A69-A76.

64. Teasdale JR, Abdul-Baki AA, Mill DJ, Thorpe KW. Enhanced pest management with cover crop mulches. Acta Horticulturae 2004;638:135-140.

65. Tindall JA, Beverly RB, Radcliffe DE. Mulch effect on soil properties and tomato growth using micro-irrigation. Agronomy Journal 1991;83:1028-1034.

66. Tolk JA, Howell TA, Evert SR. Effect of mulch, irrigation and soil type on water use and yield of maize. Soil Tillage Research 1999;50:137-147.

67. Tremelling MJ, Mcsorley R, Gallaher RN. Effect of winter cover crops on soil surface invertebrate community. Soil Crop Sci. Soc. Florida Proc 2002;62:7782.

68. Uppal DS, Khurana SMP, Pandey SK. Influence of preharvest mulching for curing of tubers on potato chip colour and processing parameters. Journal of the Indian Potato Association 2001;28:176-177.

69. Van Derwerken JE, Wilcox LD. Influence of plastic mulch and type and frequency of irrigation on growth and yield of bell pepper. Horticultural Science 1988;23:985988.

70. Vander Zaag, Demagante A, Acasia R, Domingo A, Hagerman H. Response of solanum potatoes to mulching during different seasons in an isohyperthemic environment in the Philippines. Tropical Agriculture (Trinidad) 1986, 229-239.
71. Wang Z, Zhao X, Wu P, Chen X. Effects of water limitation on yield advantage and water use in wheat (Triticum aestivum L.)/maize (Zea mays L.) strip intercropping. Eur J Agron [Internet] 2015;71:149-159.

72. Waterer DR. Influence of soil mulches and method crop establishment on growth and yields of pumpkin. Can. Journal of Plant Science 1999;80:385-388.

73. Waterer DR. Effect of soil mulches and herbicides on production economics of warm-season vegetable crops in a cool climate. Hort Technology 2000;10:154-159.

74. Weber CA. Biodegradable mulch films for weed suppression in the establishment year of matted-row strawberries. Hort Technology 2003;13:665-668.

75. Wien HC, Minotti PL, Grubinger VP. Polyethylene mulch stimulates early root growth and nutrient uptake of transplanted tomatoes. Journal American Society of Horticultural Science 1993;118(2):207-211.

76. Wien HC, Minotti PL. Growth, yield and nutrient uptake of chili as affected by plastic mulch and initial nitrogen rate. Journal American Society of Horticultural Science 1987;112:759-763.

77. Wilson DJ, Jefferies RL. Nitrogen mineralization, plant growth and goose herbivory in an arctic coastal Ecosystem. Journal of Ecology 1996;84:841-851. 